\title{
G. Ossom-Batsa
}

\section{RITUAL AS MECHANISM FOR SECURING LIFE AND AVERTING EVIL AMONG THE KROBO'}

\section{ABSTRACT}

Ritual is one of the ways in which a group of people or a believing community expresses in concrete terms their faith in a deity(ies). Two of the many functions of rituals are to secure blessings from the deity or to ward off evil. This article studies four Krobo rituals to explore the ultimate meaning of life in Krobo worldview: material and spiritual wellbeing. The fight against sickness, misfortune, evil and other disasters provides the framework within which they express their dependence on their creator by means of rituals. To the Krobo life without the divinity cannot attain its fullness; hence the constant appeal to the divinities for protection and blessings.

\section{INTRODUCTION}

Ritual communication among the Krobo ${ }^{2}$ expresses their understanding of what it means to live and to die. Krobos believe that rituals influence the deities and spiritual beings, thus securing desirable results, namely salvation or wellbeing. ${ }^{3}$ Rituals cause the divinities to be benevolent towards human beings.

1 Interest in this topic began in the years 2001-2002, when I was a postgraduate student in Missiology at the Pontifical Gregorian University in Rome. Field work and collection of data, however, took place between June 2003 and August 2004 at Agomanya, when I was appointed lecturer in the Department for the Study of Religions at the University of Ghana, Legon.

2 According to Huber (1966:140; 1980:246), the Krobo are one of the seven Adangme tribes in the southern basin of the Volta in Ghana.

3 This is in line with what Sarpong states about African religions in general:

The African has a pragmatic and utilitarian outlook on religion: religion must prevent man from being harmed; religion must make man happy; religion must neutralize the evil forces, both physical and psychical that surround man or else it loses its meaning (Sarpong 1975:42).

See also Cox (1992:83-117); Akrong (2001: 9-11); Kudadjie (1983:170-176). For a discussion of African traditional religions in general, refer to the following important works: Idowu (1975); Mbiti (1969).

Rev. Dr. George Ossom-Batsa, University of Ghana, Department for the Study of Religions, P.O. Box LG 66, Legon, Ghana. E-mail: ossom @libero.it. 
This article discusses four Krobo rituals (sowing, harvesting, birth and the naming of twins) with regard to the symbols, gestures and prayer formulas that accompany them in order to show how these capture the worldview of the Krobo. ${ }^{4}$ Symbols and gestures help to channel and control emotions in order to maintain a bond between the members of a community and a divinity on one hand, and among individual members, on the other. The article will first consider rituals directly related to the land, and then those related to the life cycle of the human being. Finally, the conclusion will summarise the main findings of the investigation.

\section{RITUALS RELATED TO THE LAND}

Among the Krobo, the earth, Zugba, is regarded as the spouse of Mau, and therefore as a goddess. Parrinder (1949:38) records a similar belief among the Ashanti where the earth, Asase Yaa, is sometimes regarded as a consort of Nyame. Zugba has no specific cult in Kroboland. However, in most prayers accompanying libations, Zugba is usually addressed together with Mau. This implicit reference to Zugba is not surprising, as Mau himself has no ostensible cult.

Related to the sacredness of Zugba is the aspect of fertility, the potential to produce offspring. As the ancient Krobo were farmers, the fertility of the land was crucial for them. ${ }^{5}$ In the past, the survival of the tribe depended, to a large extent, on their crops. If their farms failed, they would starve to death. This explains why the Krobo did not consider farming solely as a commercial activity, but rather as a religious activity that contributed to the wellbeing and survival of the tribe.

The feminine gender of Zugba appears to be related to her generative power. Seeds buried in the earth germinate and produce food crops on which human beings and other animals feed in order to be healthy. This phenomenon can be compared to the process of reproduction in females. It is therefore logical for the Krobo to look at Zugba as the female partner of Mau. However, there are no creation myths among the Krobo, suggesting that the creation of human beings was the result of the sexual union between Mau and Zugba. ${ }^{6}$

$4 \quad$ The inter-play between religion and culture is one of the liveliest issues among contemporary theologians in general and African theologians in particular. Refer to the Faith and Cultural Series, Orbis Books, Maryknoll, New York. Specifically dedicated to the theme, see, for example, Schreiter (1991); Gibellini (1994); Luzbetak (1989); Imasogie (1983); Kato (1976); Shorter (1977).

5 Compare with a similar notion found in Ancient Israel where the people went after fertility gods (baalim and asthoroth) in Palestine to ensure good crops and large families (cf. 1 Kings 18:21; see also Jer. 7:9; 11:13).

6 This lacuna may be due to the fact that the Krobo never talk in public or openly about sex. Sex and discourses about sex are reserved for the private forum. The Krobo probably regard it as disrespectful or a taboo to talk about the sexual activity of their Supreme Being. 
Because of the generative role attributed to the earth, rituals associated therewith are mainly those related to farming. The two main rituals are the ritual of sowing and the ritual of harvesting the first fruit. These form the background to the entire farming season.

\subsection{The ritual of sowing}

The ritual that precedes the sowing of new crops is referred to as the "cursing ritual". It takes place in two stages: pouring libation for rainfall, and expelling hunger and evil from the community. Both stages of the ritual are performed at the beginning of the planting season, when the farmers have finished preparing their farmlands and are ready to sow new crops.

\subsubsection{The pouring of libation for rainfall at the shrine}

At an appointed time fixed by the priests of the two important tribal sanctuaries (Okumo and Nana Klowekı) representatives of the various clans gather in the courtyard of the sanctuaries for the ceremony (Huber 1980:247). When the people are assembled, the officiating priest stands outside the shrine and, using millet drink (prepared from the produce of the previous year), pours libation on their behalf and prays for "abundant rainfall" so that the crops of the subsequent season may thrive well and the farmers have a good harvest. ${ }^{7}$

The following are examples of words that accompany the libation:

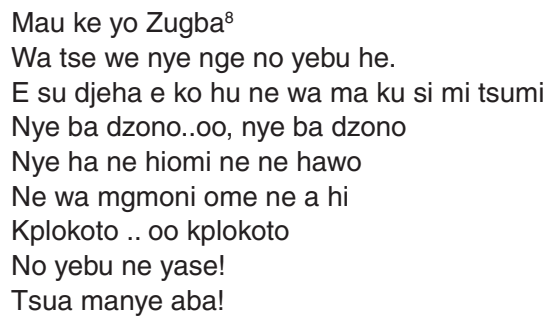

$7 \quad$ For a discussion on libation in the Old and New Testaments and its implication for African Christianity, see Osei-Bonso (2005: 80-83). In his book the author and Catholic Bishop expresses a strong conviction that libation could be Christianised by changing the formulas in the prayers.

8 Like all other Krobo rituals there is no fixed wording. The formula is the same but the wording varies, depending on the eloquence of the officiating priest. The words in the prayer were recorded in an interview with Okumo priest of Odumase-Mampong, Nov. 2003. 
English translation:

\author{
Mau and his consort Zugba \\ We call you not for any mishap \\ A new year has begun, \\ and we are about to perform the annual ritual \\ May you come and bless everything \\ Let there be abundant rainfall; \\ And our crops thrive well. \\ Cast out all evil! \\ And bless us $!^{9}$
}

\title{
2.1.2 "Expelling hunger" (Kodaa Kpami)
}

The libation for rainfall is immediately followed by Kodaa kpami, "expelling hunger and evil" from the community. Hunger is considered an enemy of human beings and a threat to human existence, and it must therefore be driven out of society if humankind is to attain growth and wellbeing. One of the ways to combat hunger, in the traditional worldview of the Krobo, is to eliminate everything that threatens harmony in the world and that prevents a good harvest. One of such perils is believed to be "evil people in the community". To the Krobo, people with evil intentions destroy farm products and consequently cause hunger. Hence, kodaa kpami is aimed at destroying such human agents within the community in order to pave the way for high productivity (cf. Huber 1980:247).

The etymology of the word kodaa is not clear, but kpami means "hooting". The kodaa kpami has two parts: the "ritual cursing" and "the profession of integrity" first by the priests and then by the worshippers.

Raising his eyes to the heavens, ${ }^{10}$ the officiating priest solemnly calls out in a loud voice:

Gbie ha nyuali!

Gbie ha abusiamitseme!

Gbie ha hiali!

9 The English translation is mine.

10 The gesture (raising eyes towards the heavens) of the priest suggests that the Krobo believe the abode of their Supreme Being is in the heavens. To address God, one must therefore look towards the heavens where he dwells. This posture is assumed in all libations where Mau is addressed. 
Translation:

Cursed be those who kill by casting spells!

Cursed be those who kill through evil names!

Cursed those who kill through witchcraft!

These curses are repeated twelve times,$^{11}$ and each time the people respond with a loud yell and stamp the ground. The three agents of evil among the Krobo named in this prayer of exorcism are nyuali, abusiamtseme, and hiali. The nyuali are human beings believed to inflict sickness and death on others by casting evil spells on them by means of some efficacious magical word spoken or sung. Abusiatseme are those who have recourse to evil spirits (mumi yayam), manipulating them to harm or kill a person or group of people. On the other hand, Hiali are witches, persons believed to be possessed by evil spirits, whose principal activity is to destroy human life and all that contributes to the progress of human beings.

The presence of these human agents of evil in society is believed to threaten human, plant and animal life. If society is to make any progress, and its members obtain good health, the evil-doers must be controlled. "Ritual killing" or "annihilation" of the evil-doers in society is suggested by the gesture of stamping the ground in the ritual. This spiritual meaning given to the gesture has a pragmatic effect on the life of the practitioners of the ritual, who feel assured of the action of the deity on their behalf.

Related to the "ritual killing" of evil-doers is the profession of individual innocence. After the evil-doers are cursed, each participant, beginning with the priests, solemnly professes his/her innocence in the form of an oath. This act is to demonstrate publicly that one has not done any evil in hiding. If a person is guilty of any evil, this was revealed when the prayer is recited in the presence of the deity. A bizzare thing may happen to the person, for example, s/he may lose consciousness or become dumb or even die. ${ }^{12}$

Huber (1980:248) records the following prayer formulas for the profession of innocence:

E-e-e, imi kloweki wono, muoeno i daasi ne i nge kita kaa e.

Ke i gbe noko,

11 The repetition of the curses twelve times is interpreted by most informants in Agomanya in relation to the twelve "Wetso" which constitute the Krobo tribe. Performing the act twelve times, they suggest, means the purification of the entire tribe.

12 According to a priest of the djebiam clan (Agomanya), in ancient times when the population was meagre and uniform everybody in the village went through this text to demonstrate his/her integrity. 
Ossom-Batsa Ritual as mechanism for securing life and averting evil

aloo i nyua noko o

aloo i pue ho

aloo i pue i nyemi ko ngmo

aloo i pe noyaya ko nge djeno mi o

i mi kloweki wono

i pue nana kloweki hemi si.

Nana kodaa ne enu mi.

Ke i mi kloweki wono o

I pewe nonome e ko o -

I gbi noko,

i puewe ho,

nee i puewe noko bie,

i yi lakpa dase,

se noko po ninome ngo wo ihe o;

kusie ha djama tse o!

Nana kloweki kodaa ne nule!

\section{English translation:}

Eh, I Nana Kloweki's priest, today I stand here to witness to myself.

Should I who stand before you

Have slain any one,

or killed one through medicine,

should I ever have destroyed a woman's pregnancy,

or spoiled my brother's farm,

or done evil things in the world

— I who am in charge of Kloweki's cult -

it would be a sinful action on my part,

a scandalous defilement of Nana Kloweki!

Should I really have done such things,

then call Nana's Kodaa upon my head!

If I Kloweki's priest,

have never done such things,

If I have never killed a person,

never destroyed a pregnancy,

never injured someone's name

nor borne false witness against a person,

and if in spite someone accuses me

of having done such things,

this will be a great offence on his part!

Nana Kadaa's curse upon his head! 


\subsubsection{Interpretation of the prayer}

The structure of the ritual suggests that it embraces both those who are physically present at the sanctuary and those who are absent. In other words, everybody in the village or town is brought under the spiritual powers that accompany the prayer of the priest. According to the priest of Nana Klowerki and an elder at $A b u d e,{ }^{13}$ this is important since not every member of the village or town attends the ceremony. Those present at the sanctuary have the opportunity to profess their integrity, i.e. to demonstrate their innocence. On the other hand, those who are absent are under the curses proclaimed by the priests.

The text of the prayer is elaborate and calls for a serious examination of conscience and an open confession in the form of a profession of innocence. It is also significant to note that the profession of innocence takes place before the deity who is called upon as arbitrator.

Some offences or sins are specified: murder, abortion, bearing false witness against a neighbour, and using medicine to destroy other people's farms. These are considered the most grievous sins according to the Krobo moral code. Such an interpretation is suggested by the addition, "or done evil things in the world". It is assumed that other bad behaviour resorts under such evil deeds. The emphasis appears to permeate any activity that destroys life.

As the confessions are public, all those present listen to and assist at the confessions of other people. This promotes confidence and trust among the participants, which in turn helps to build the communal spirit. Accordingly, bad behaviour is not only a personal matter, but also has a social dimension. An individual's actions affects the entire community.

Similarly, the "curse" pronounced by the officiating priest is a means to purge the entire environment and community of evil. The ritual act is believed to neutralise the forces of those members who threaten the social wellbeing of the community with their evil intentions. A person found guilty of any of the offences mentioned in the prayers will either be inflicted with sickness or be struck dead by the deity.

The gesture of "stamping their feet" after the confessions suggests the belief that the deity will kill the culprits. This act is a symbolic killing of malefactors in the community.

It is only after this ritual act that farmers can plant their crops as the environment is then believed to be cleansed of malefactors and the blessings of the gods secured. It was taboo in ancient times for farmers to plant new crops.

13 Ideas in the interpretation of this prayer were recorded at Abude in a personal interview with Papa Sackitey, a family elder, August, 2005. 
They ran the risk of having their farm destroyed or of a bad harvest if this injunction was not respected. Farmers therefore anxiously and joyously awaited the performance of this ritual before planting their seedlings. They were confident of a good harvest the following season once the ritual of kodaa kpami had been performed. ${ }^{14}$

\subsection{The offering of the first fruit (Nii ano fiami)}

Harvesting time is one of the most joyous moments for the entire village or town, but especially for the farmers who harvest the fruits of their labour. The ritual of the offering of the first fruit is known as nii ano fiami ${ }^{15}$ (offering of things). It precedes harvesting and any consumption of the new crops.

When the millet crop, the traditional staple food of the Krobo, has matured, the chief priest of Okumo selects an appropriate day and informs the clan heads and elders. They, in turn, summon the people to the sanctuary of the deity.

Some of the new millet is used to brew millet drink for the ritual. The ritual is basically a thanksgiving for blessings received in the previous farming season. When all the people are gathered in the sanctuaries of the deities the ceremony begins with the officiating priest pouring libation, i.e. the newly brewed drink.

The following is an example of a prayer that accompanies the pouring of libation (cf. Huber 1980:249).

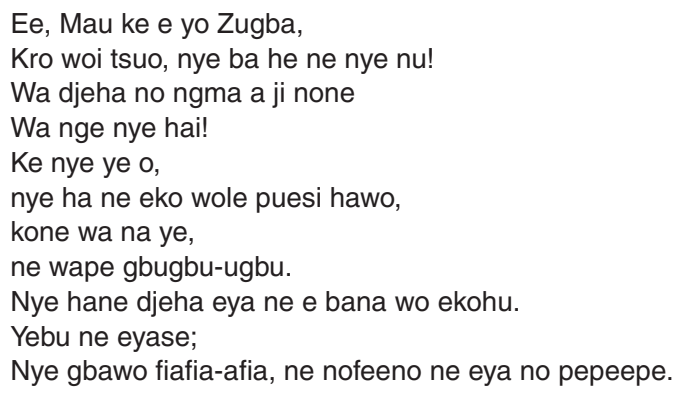

14 In the event that some natural calamity such as flood or excessive dryness should happen and the harvest turns bad, the interpretation given is that the deities have meted out their revenge as a result of an offence committed against them. To the Krobo nothing happens by chance, and scientific explanations have little relevance. The question is always "why did it happen?" and not "how did it happen?"

15 nii ano fiami literally means "sprinkling of the items/things" which suggests blessing of the first fruit. This blessing is effected by presenting the first crop to God. 
Translation:

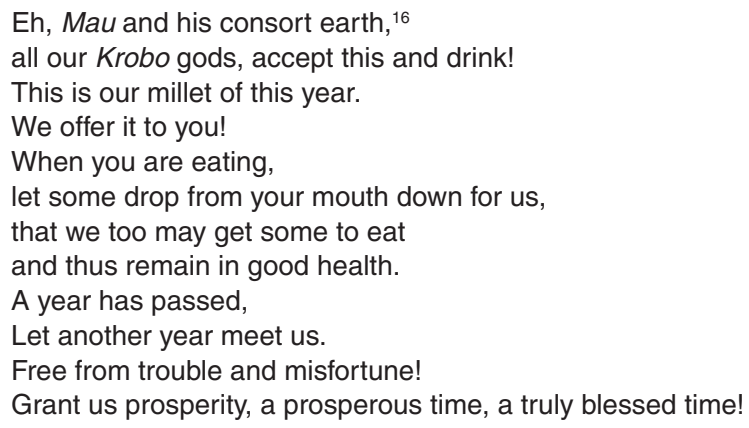

\subsubsection{Interpretation of the prayer}

Mau, the Supreme Being, is named at the beginning of the prayer, suggesting the primacy of Mau among the divinities. Unlike the minor gods and the ancestors who both bless and punish, Mau is always regarded and portrayed as a benevolent God; Mau does not punish but allows punishment to be meted out by other divinities.

As the ritual concerns the entire tribal group, all the deities of the Krobo territory are called upon to receive, accept and eat the offering. This anthropomorphic view of the gods is further emphasised as the gods are believed to be the actual owners of all the fields and their produce. Once the gods have taken their share of the crop, man (the farmer) can also feed himself: "Let some drop from your mouth that we too may get some to eat".

To the traditional Krobo, one eats to live; in other words, people eat to have good health. Good health in this context means absence of sickness and misfortune, but mostly, prosperity and wellbeing (Huber 1980:249).

The prayer ends by soliciting blessings for the New Year from the gods. The people and all the activities related to the land are entrusted to the gods in the New Year. In this prayer, as in that for "cursing hunger", the emphasis is on the theme of blessing on the one hand, and on protection from evil, on the other.

16 As explained earlier, in this prayer Mau is addressed together with his consort, Zugba. 


\subsubsection{Offerings to the deities}

The presentation of the new crops to the deity follows the libation. Some millet drink and sibaa ${ }^{17}$ are set before the deity with the shrine closed. It is believed that the deity comes to eat what is set before it. Whether the food set before the deity is found in the shrine the following day or not, it is believed that the deity has spiritually eaten it.

Once the deity has been served its portion, the chief priest tastes the new crop and all are then welcomed to eat from the new crops from their farms. The distribution of food to the deity marks the official beginning of the harvesting period. Coursey and Coursey (1963:449) note that "the rites are believed to protect against sickness when eating the new crop".

During the following eight days, which constitute the sacred period, New Year sibaa is offered to the spirits, the ancestors and the minor deities. In ancient times, within the eight days of celebration, each family presented sibaa to the ancestors and sprinkled crumbs of food on the ground after every pasta or meal. Individuals and families present their offerings (normally part of the crop from their farms) to the deity via the priest of the shrine. There is no explicit indication of what happens to the offerings brought to the shrine. A few informants noted that part of the offering was usually left to rot at the shrine. ${ }^{18}$ The remaining part was consumed by the custodians.

The ritual of the first fruit takes place within the context of the annual ngma yemi festival, which celebrates the joy of the new crops. Ngma means food, and yemi means eating. Thus etymologically ngma yemi is "eating food". The ngma yemi festival, which in the past brought most families dispersed for farming reasons to the traditional centre, Odumase, to celebrate the blessing of the new crops with dances and songs.

Besides its religious significance, the festival is also an occasion for socialisation (cf. Coursey \& Coursey 1963:449). It is a period of happiness, a period when individuals and families exchange visits. Family meetings are held; disputes between families and marriage quarrels are also settled.

17 Sibaa is a traditional dish prepared with boiled mashed yam (Klo hie) mixed with cooked eggs and palm oil (red oil). This dish is normally referred to in the Krobo culture as "the food of the dwarfs".

18 The priest of Okumo, one of the principal shrines in Manya Krobo traditional area, explains that the gifts offered to the deities are meant for the deities and their servants, the priests. What is offered is shared between the deity and the priests. Outsiders may not partake of it. Anybody who does so may die or experience a calamity. 


\subsection{The significance of work among the Krobo}

To the Krobo, work has three dimensions: economic, social and religious. Notarangelo (1993:5-25) makes this observation about rural dwellers in general. Among the ancient Krobo farming was the main occupation of most families. Though there were other activities or work, for example, basket weaving, carpentry, etc., these were not considered full-time work, but hobbies.

The discussion of the rituals related to farming has revealed the relationship between farming and faith, and also how man co-operates with God by working the land, thus improving his own life.

\subsubsection{The contribution of farming to life}

By tilling the land man is able to produce sufficient food to maintain life. Thus "if human life is to continue, production of food must go on", goes a Krobo "saying". The relationship between the production of food by tilling the land and the life of the people has always been very important to the Krobo. The daily livelihood of most families depended on farm crops. And this led to a high respect for farming and the development of various skills in farming.

Besides the production of food, work also promotes and improves social ties. By working together, individuals and people within the family share each other's burden and hardship. The many hours spent together on the fields help build authentic relationships. Relationships created in living and working together strengthen unity and co-operation. Accordingly, in the Krobo ethos, humankind must be in a relationship with nature, other people and God. In other words, the human being is nothing without a relationship with God, others and nature.

\subsubsection{The place of farming in Krobo traditional religion}

Any activity that contributes to the preservation of life is crucial to the Krobo. Such an activity is regarded as a blessing from the gods and the ancestors. Farming or food production is believed to have a religious significance. To produce food to feed the family and others is to co-operate with God in sustaining human life. ${ }^{19}$ Evidently, the land belongs to God, and God grants a good harvest, but man is endowed with intelligence and given the task to co-operate with God. Hence, not working amounts to a refusal to co-operate with God. This is normally punished with unfruitful life or sickness.

19 This idea compares with the account in Gen. 2:4-25, which focuses on humankind, and describes its place in the garden of Eden as well as its role in protecting it, and bringing the world to its full potential. 
In conclusion, according to Krobo ethos, Mau, the creator God, is still active in creation through the activity of humankind. Mau has endowed human beings with intelligence to enable them to cultivate the land and feed on the produce for sustenance.

\section{RITUALS RELATED TO THE RITES OF PASSAGE}

Birth, puberty, marriage and death, which in anthropological terms are referred to as rites of passage, are considered to be the four main stages in a person's life. ${ }^{20}$ Through gestures and accompanying words, a neophyte is conferred with a new status and is thus introduced into a new group or unit of society. For the purposes of this article, the ritual of birth will illustrate this point.

\subsection{The ritual of birth}

From experience the ancient Krobo know that biological life begins with the coming together of woman and man; however, they still attribute the origin of new life to Mau. A pregnant woman is said to "have gone to draw water from the cistern of the gods" (e ho Mau aje pa ya). Thus childbirth is considered not only a physical capability, but also a spiritual reality. There is always a spiritual dimension to birth since the newborn is considered a blessing from the gods and the ancestors. In fact, the ancestors and gods are believed to have the power to either seal the womb of a woman to prevent childbirth or bless the woman with a child. This explains the spiritual nature of pregnancy.

From the moment of conception (sidami, which literary means "standing up"), the woman is bound by ritual observances in order to protect the seed in her womb. The first requirement is that she must keep the news of the pregnancy secret, and only tell her husband, as people with bad intentions could harm the baby and cause a miscarriage. The news becomes public only when the stomach begins to protrude.

During pregnancy, the woman observes the following ritual sanctions or prohibitions: She must not quarrel with anybody; she must not be involved in any mischievous deed; she must not steal, etc. ${ }^{21}$ These are meant to protect the baby in her womb from any harm, and to secure good health. Besides these, the ritual observances are also meant to protect the woman and prepare her for a safe delivery.

20 For a basic and comprehensive discussion of the question, refer to the classic work of Van Gennep (1969).

21 These ideas are from interaction with Queen mothers at Somanya-Korledje, October 2005. 
Immediately after delivery, an elderly woman washes the newborn with warm water to which special herbs have been added. The newborn is then wrapped in a piece of cloth, usually part of an old cloth of the father, and placed on the bed prepared for it. Word is then sent around to nearby relatives and friends, who come to rejoice with the family.

The joy that accompanies the birth of a baby is captured in expressions such as Bigno, (child sweet), Maule hano (it is God who gives); Mau lede (God says), and Hueni (it belongs to the intimate one). These expressions are used by those who have gathered to rejoice at the safe delivery, to indicate that a child is the joy of its parents. No other joy surpasses this for a couple. On account of this, the Krobo consider childless marriages a misfortune. Such marriages are even interpreted as a punishment from the gods for offences committed in the family, not necessarily by the couple but by a relative.

The birth of a child is regarded first as a blessing from the gods, and secondly as victory for the woman who delivers safely. Cradle songs illustrate that the child, from its first appearance in the world, is entrusted to the protection of the gods. The following cradle song is taken from Huber (1980:249):

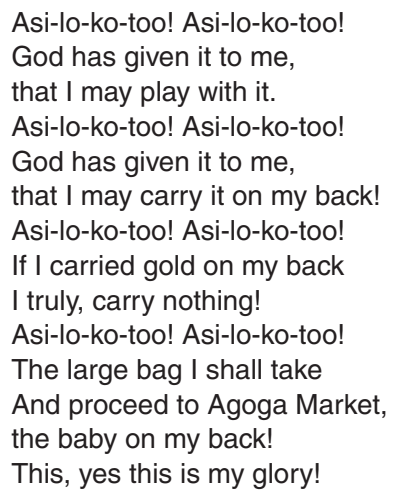

\subsubsection{Interpretation of the prayer}

The two important concepts in the prayer are the child as God's gift and the preciousness of the child's life (cf. Huber 1980:250). Though not explicitly stated, it may be inferred from the phrase "God has given it to me" that it refers to God as the creator of human beings. The awareness that the child comes from God requires the parents to see to the child's spiritual growth. Spiritual growth implies recommending the child to God for his protection, and placing the child in a continuous relationship with God and the spirits. 
It must be noted that the preciousness of the child's life is emphasised by comparing it to gold, which among the Krobo is one of the most precious items a person can possess. Only few people can afford to acquire gold. The worth or importance of a person or a family is normally measured by the amount of gold ornaments they exhibit during public festivals and feasts.

With all its value and the air of importance it bestows on the owner gold has nothing to equal "begetting a child". The voice of the mother in the song audaciously proclaims that her deep satisfaction lies in "carrying" a child on her back. In other words, to nurse a baby is an expression and fulfilment of motherhood for the Krobo woman. This must be viewed in the context of the belief that childlessness means an unfulfilled life among the Krobo. It is in the light of this that Huber (1980 251) states: "It is not things, riches which rank first, but the living person, the child which enlarges the circle of family and which ensures its reputation and continuance".

A child as God's gift is related to the understanding that the child does not "belong to the mother as a property". God who is the dispenser of all life gives or entrusts the child to the mother as a companion (God has given me that I may play with it). The idea that a child belongs to the parents and that they can do whatever they please with it is contrary to this understanding. The above prayer thus affirms the sacredness of human life and the need to preserve it.

The newborn is solemnly introduced into human society on the eighth day, when it is given a name. Prior to this, it is considered to be in transition between the spiritual world and its earthly existence.

\subsubsection{The ritual for twins (Ha domi)}

In traditional Krobo culture the birth of twins is considered extraordinary. Twins are believed to have spiritual forces which other newborn babies lack. Due to this belief twins are received or welcomed into their families with a special ritual known as ha domi. Ha means "twins" and domi means "dancing". Ha domi basically means "welcoming twins with songs and dances".

\subsubsection{On the day of birth}

The ritual for twins takes place in stages. The first stage is on the day of birth. At the news of the birth of twins, the father of the twins (if he is around) or any adult male member of the house immediately orders the news to be circulated round the household and their neighbours. On receiving the news, the female folk, singing and dancing, run to the house where the twins were born. From the house they joyously parade the streets of the village or town. The youth and men also join this dance. Those who join in the dance hold small branches 
of trees in their hands which they wave to the tunes of the songs and the music provided by beating drums, pieces of broken items (buckets, basins, cooking utensils, etc.).

Some of the popular songs are:

Ata ke Lawer lee, me le aso ne amo o-oo-oo!

lyoyo, iyo!!!

Translation:

Behold! Ata and Lawer have decided to come together. ${ }^{22}$ lyoyo, iyo!!!

Maku lee, ogbe ohe nya,

Ohemi yaya kaa nene toye!

Translation:

Maku, ${ }^{23}$ You are bad,

Your face is like the left over food of goats!

\subsubsection{Naming ceremony (Bie womi ke Bi kpo djiemi)}

This ritual takes place on the eighth day after birth, when the children are ceremonially given their traditional names. The twins are presented to the deities and ancestors by the pouring of libation to which some local gin, apketesi has been added. Prayers offered to the gods indicate that the new babies are gifts from the gods and must therefore be handled with care.

The ha domi, the ritual dance, follows the libation. Traditional songs are sung in praise of the gods and the people dance to the melodious tunes. It is a time of merry-making characterised by licentiousness. For example, the women strip half naked to participate in the dance. Insults are levelled against the parents of the twins as a way of making fun of them. This is considered a humiliation that generates health for the newly born babies and their parents.

In conclusion, many of the informants emphasise the obligatory nature of the ritual and emphasise that failure to perform the ritual will result in supernatural sanctions against the parents of the twins or the entire family (sometimes the

22 Ata and Lawer are twin names for female and male respectively. When both are males they are called Atter and Lawer or Akwetey and Akwerter, two females are called Aakor and Akweley.

23 Maku is the name of the mother of the twins. In its place the name of the father of the twins could be substituted. 
entire village). These afflictions or sanctions are believed to be caused by the twins as a revenge to register their feeling of being unwanted in the world or in their family. Some parents of twins interviewed indicated that when the rituals were ignored, the twins punished their parents by either frequently falling ill, one after the other, or by contracting a deadly disease. Once the rituals were performed they recovered and grew normally.

\section{CONCLUSION}

This article has demonstrated, by way of a phenomenological study of a few Krobo rituals, what life and death mean in the Krobo culture: wellbeing and absence of wellbeing, respectively. The analysis also showed that rituals serve as a means of combatting evil and imploring blessings in human existence. The following significant points may be drawn as conclusions to this study:

a) To the Krobo "to live" implies both material and spiritual welfare. Since the Krobo cannot access this by their own power, they must be in a constant relationship with the divine beings who are the dispensers of benevolence. To the Krobo Christian this means living daily in God through Jesus Christ. Such a life is not only personal, but essentially social, in a relationship with others.

b) The ultimate meaning of life, that is, the fullness of life, is the attainment of a fruitful life. This presupposes the recognition that there is more to the human person than the corporeal reality of the individual, that is, his nomlotso. However, salvation as wellbeing and prosperity must begin in this worldly existence (cf. Huber 1980:255). The fight against sickness, misfortune, evil and other disasters provides the framework within which human beings express their being in and dependence on their Creator. The Krobo is deeply aware that life without the divinity cannot attain its fullness; hence the constant recourse to the divinities for protection and blessings. This provides the space for an encounter between the gospel and Krobo culture.

c) A critical study of the culture of a people is necessary to discover the values it shares with Christianity (cf. Carrier 1989). ${ }^{25}$ The shared values may provide the basis and starting-point of a "missionary" or "evangelical" dialogue with the people. In this way Christianity may not appear to be a foreign religion imposed on the people, but rather an aid in their search for an authentic way of life. The Christian message then becomes a challenge to the people to review their belief system and consequently re-organise their ritual system (cf. Osei-Bonso 2005).

24 For a detailed reflection on salvation in African Christianity, refer to Akrong (2001:1-29).

25 Though most scholars agree that theology must be contextualised, they approach the subject using different methods. For a discussion of the different models of contextualising theology, see Bevans (1992). 


\section{BIBLIOGRAPHY}

Akrong, A.

2001. Salvation in African Christianity. Legon Journal of Humanities 12:9-18.

Bevans, S.L.

1992. Models of Contextual Theology. Maryknoll, N.Y: Orbis Books.

Carrier. H.

1989. Gospel message and human cultures: From Leo XIII to John Paul II. Pittsburgh: Duquesne University Press.

Cox, J.L.

1992. Expressing the sacred: An introduction to the phenomenology of religion. Harare: University of Zimbabwe Publications.

Gibelini, R (ED.)

1994. Paths of African Theology. Maryknoll, N.Y: Orbis Books.

HuBer, $\mathrm{H}$.

1963. The Krobo: Traditional social and religious life of a West African people. Fribourg: Editions of St. Paul. Studia Instituti Anthropos 16.

1980. Outlines of ultimate reality and meaning in Krobo ritual. Ultimate Reality and Meaning 3(4):245-255.

IDOWu, E.B.

1975. African Traditional Religion. Maryknoll, N.Y: Orbis Books.

IMASOGIE, O.

1983. Guidelines for Christian Theology in Africa. Achimota: African Christian Press.

Kato, B.H.

1976. African cultural revolution and the Christian faith. Jos: Challenge Publications.

KUDADJIE, J.N.

1983. How morality was enforced in Ga-Adangme tribe. In: E.A. Ade (ed.), Traditional Religion in West Africa (Ibadan: Sefer Books), pp. 170-176.

LUZBETAK, L.

1989. The church and cultures: New perspectives in missiological anthropology. Maryknoll, N.Y: Orbis Books.

MBITI, J.S.

1969. African religions and philosophy. London: Heinemann.

Osei-Bonso, J.

2005. The inculturaton of Christianity in Africa: Antecedents and guidelines from the New Testament and the Early Church. Bern: Peter Lang. New Testament Studies in Contextual Exegesis. 1. 
Ossom-Batsa Ritual as mechanism for securing life and averting evil

PARRINDER, G.

1949. West African religion: A study of the belief and practices of the Akan, Yuruba, Ibo and the kindred peoples. London: Epworth Press.

SARPONG, P.

1975. Media of revelation in African traditional religion. Ghana Bulletin of Theology 4(8):42-52.

SCHREITER, R.J. (ED.)

1991. Faces of Jesus in Africa. Maryknoll, N.Y: Orbis Books.

SHORTER, A.

1977. African culture and religion. Maryknoll, N.Y: Orbis Books.

$\begin{array}{ll}\text { Keywords } & \text { Trefwoorde } \\ \text { The Krobo } & \text { Die Krobos } \\ \text { Ritual } & \text { Ritueel } \\ \text { Evil } & \text { Boos } \\ \text { Blessing } & \text { Geseënd } \\ \text { Life } & \text { Lewe }\end{array}$

